\title{
Aquilino Ribeiro e o caderno de uma guerra mundial a nascer
}

\author{
Aquilino Ribeiro and the notebook of a rising World War
}

\author{
CARINA INFANTE CARMO \\ Universidade do Algarve/ Universidade de Lisboa - Algarve/Lisboa - Portugal
}

D

Resumo: Em 1934, Aquilino Ribeiro publica o diário É a guerra onde fixa a visão de estrangeiro sobre Paris, que mergulha gradualmente na escalada da I Guerra Mundial. As acusações de germanofilia dirigidas a Aquilino vêm da sua "imoderada franqueza" sobre o campo francês, revelada nesta obra. Escandido pelos dias que vão do eclodir do conflito ao regresso do escritor a Portugal, no fim de Setembro de 1914, É a Guerra é um texto híbrido que não foge ao registo ensaístico e jornalístico. Na mistura deliberada de géneros, Aquilino escreve a memória pessoal do século XX, a nascer a ferro e fogo entre derivas nacionalistas e imperialistas. Fala da efervescência humana da cidade de Paris, já transfigurada pelos crescentes sinais da guerra e que, para ele, em grande medida, se torna mal-amada e motivo de observação perplexa e reactiva.

Palavras-chave: Diário; I Guerra Mundial; Antibelicismo; Paris, Paisagem urbana

\begin{abstract}
In 1934, Aquilino Ribeiro publishes his diary É a Guerra [It is War], where he fixed his literary gaze over, gradually determined by the escalation to I World War. At this time Aquilino Ribeiro was often accused of germanophilia. These accusations can be justified by his tempered sincerity about the French side, as we can confirm in this work. É a Guerra follows on a daily basis the time between the outbreak of the conflict and the writer's return to Portugal, at the end of September 1914. This is a hybrid book which explores both the essayist and journalistic style. With the mixture of genres, Aquilino Ribeiro writes his personal memory of the first decades of the $20^{\text {th }}$ century: of a time when violence promoted by nationalists and imperialists expands. Aquilino talks about the human effervescence of Paris, already transformed by increasing signs of war. Therefore Paris becomes in his writing mostly an unaffectionate city observed in a perplexed and reactive way.
\end{abstract}

Keywords: Diary; I War World; Antibelicism; Paris, Urban landscape

Paris é, porém, como o mar: muda ao infinito; quem pode dar as suas cambiantes?

(RIBEIRO, 1934, p. 238)

A experiência do exílio parisiense proporcionou a Aquilino Ribeiro a abertura da sua geografia sentimental numa obra literária que privilegiou a humanidade primitiva e pícara da aldeia da sua Beira natal, sem se limitar a ela e, muito menos, sem se acantonar num regionalismo pitoresco. Entre 1908 e 1914, colheu o estímulo das artes e da vida intelectual da grande metrópole da Belle Époque, onde desaguava a modernidade estética do novo século. Frequentou museus, teatros, livrarias e a licenciatura de Filosofia na Sorbonne, onde recebeu a lição de mestres como Lalande, Lévy-Bruhl ou Durkheim. Conviveu com escritores e artistas plásticos portugueses. Disso deixou testemunho no estudo sobre o pintor Manuel Jardim, em Por Obra e Graça (1939), na biografia do caricaturista Leal da Câmara (1952) ou na colecção de crónica e polémica Abóboras no Telhado (1955). Em paralelo, não é despicienda a ligação que fez daquela cidade com uma filosofia libertina do amor, colhida nas leituras de Anatole France e projectada no bálsamo sedutor das suas personagens femininas. Assim o lemos em "A inversão 
sentimental", de Jardim das Tormentas (1913), em "Os olhos deslumbrados" e "Maga", de Filhas de Babilónia (1920), ou em O Arcanjo Negro (1947).

É, contudo, no diário pessoal É a Guerra, escrito em 1914 e publicado vinte anos depois, que Paris merece mais atenção da parte de Aquilino $^{1}$. Cada página do diário segue a par e passo as movimentações das forças beligerantes, sobretudo da França, e a posição oficial da jovem República portuguesa, na pessoa do seu ministro plenipotenciário em Paris, João Chagas. Entre 1 de Agosto e 26 de Setembro de 1914, tenta captar-se a alma da cidade sob a óptica de um eu em terreno incómodo e até adverso, atendendo à sua condição de estrangeiro e à sua posição antibelicista e, de certo modo, germanófila. Nessa conformidade, opta por um discurso partidário (na acepção retórica do termo) que denuncia no lado francês a deriva nacionalista, a manipulação dos media e dos políticos, assim como a ilusão de uma guerra-relâmpago que, em breve se saberia, se ia arrastar, na frente ocidental, na penosa e mortífera confrontação das trincheiras.

Não é, pois, da matéria íntima que este diário trata. Fala aqui e ali de um ou outro amigo, regista impressões pessoais do quotidiano parisiense mas não contempla pensamentos mais recônditos e pormenores de teor autobiográfico da esfera privada, como a experiência de ter sido pai, em Fevereiro de 1914, ou de ser casado com uma mulher alemã nessa Paris transtornada pela exaltação nacionalista. Pode dizer-se que as últimas entradas e em particular o explicit da obra, já escrito em Bordéus, libertam mais a emoção e a marca autobiográfica de um sujeito ciente do desastre da guerra e atingido pelo regresso iminente a Portugal. Não esconde a náusea por aquele "horrendo ataque de epilepsia universal" (RIBEIRO, 1934, p.296), o pessimismo histórico-social e o apego anticosmopolita e desolado à aldeia natal, nos antípodas de uma metrópole que entretanto se desfigurava:

Quem me dera já em Portugal, na minha aldeia, dormente desde que o primeiro homem ali ergueu uma palhoça! Fechar-me nela como em deserto e nunca mais ler a maldita palavra humana em livros e jornais! Esquecer-me na casa tranqüila dos horrores que nestes meses tenho visto e pulsado até sempre, até o dia em que na poeira inerte da terra vá delir-se o colóide patusco colóide - em que se resume, segundo parece, esta máquina de viver. (RIBEIRO, 1934, p. 299)

O livro versa matéria política, a natureza da guerra, em primeiro lugar, como indicia o título, e as

\footnotetext{
1 Importa referir o ensaio de Jorge Reis intitulado Aquilino em Paris (1987) onde se relata a derradeira viagem do escritor à capital francesa, em Junho de 1961. Trata-se de uma "biografia romanceada" (VIDIGAL, 1988, p. 174), entrecruzada com trechos e depoimentos aquilinianos e especialmente focada nos tempos do seu primeiro exílio em Paris e nos artigos que publicou nessa fase.
}

circunstâncias que, na sua opinião, tornaram inevitáveis o deflagrar do conflito e a correlata reacção dos parisienses. A unidade temática da obra é moldada pelo ritmo diário de uma escrita direccionada para um tópico único e para a elaboração argumentativa de um ponto de vista que tenta ser bem escudado. Embora situado no cimo agudo do instante, para usar a metáfora que Philippe Lejeune (2005, p. 85) atribui ao diário, Aquilino controla a possibilidade da deriva ou da discontinuidade que lhe permite desviarse do assunto central do livro ou que suspende o acto da escrita, por efeito de qualquer livre associação de ideias. Tal restrição não impede, entretanto, como veremos adiante, que seja diverso o material incorporado no diário.

As notícias da escalada da guerra têm tradução no vigor crescente do registo que acompanha a aproximação do seu regresso a Portugal. Não será, por isso, excessivo identificar no diarista um incansável fim argumentativo. Num primeiro nível, é óbvia a intenção de recusar à França o epíteto de luz civilizadora do Ocidente, dado o seu papel pernicioso na cena internacional, movida pela revanche nacionalista que alimentou contra a Alemanha desde a Guerra Franco-Prussiana de 1870-1871. Essa é uma teoria marcante de toda a obra. Informado por factos históricos contemporâneos, por memórias de guerras passadas, por documentação coeva (jornais, anúncios e vozes da rua), Aquilino é um repórter e cronista, com fôlego ora reflexivo ora oratório: capta as ondas afectivas das ruas por onde circula para colher notícias e reage com veemência à alienação nacionalista e xenófoba e aos seus atiçadores mais tenazes, a imprensa e a escola.

Logo na primeira entrada do diário, Aquilino Ribeiro declara-se admirador confesso dos esforços antimilitaristas do líder socialista Jean Jaurès, assassinado por extremistas da Action Française, a 31 de Julho de 1914: "Em meu peito choro-o como se fôssemos do mesmo lar." (RIBEIRO, 1934, p.20). Além disso, virá a contestar mais à frente o comportamento dos dirigentes socialistas que esmagadoramente pela Europa cedem à demonização chauvinista da Alemanha e caem na tentação do nacionalismo e da guerra, alinhando em governos de União Sagrada.

Num segundo nível de contestação, a máquina retórica do diário vira-se contra João Chagas: não se escusa a argumentos racistas, já que qualifica a tez mestiça de "Mossiê Chàgáss" (idem, p. 261) como "tara física" (idem, p. 152) que o torna inepto para desempenhar um cargo diplomático numa capital europeia: é, aliás, repetida a caricatura física e o relato demolidor da sua alegada negligência para com os concidadãos portugueses em aflição e da sua "insolência" (idem, p. 71) no meio diplomático, nomeadamente quando se muda para Bordéus onde seria instalada a capital francesa, tendo em 
conta o risco de Paris ser ocupada por tropas alemãs. A 15 de Agosto, qualifica-o como "fornecedor do talho" (idem, p. 149), por ele fazer a defesa intransigente da entrada de Portugal na Guerra.

$\mathrm{Na}$ verdade, o empenho de Chagas para fazer de Portugal um país beligerante é de tal ordem que, a 3 Setembro, virá a Lisboa reunir-se com o ministro dos Negócios Estrangeiros e com os representantes diplomáticos da Inglaterra e da França em Portugal. Queria a todo o custo que Portugal e a República ficassem em pé de igualdade com as grandes nações europeias, em oposição à Espanha neutral. Defendia que este era um momento único na história do país, dado que, pela primeira vez, poderia apresentar-se como credor da Inglaterra: "Pela primeira vez na historia da nossa velhissima alliança ter-lhe-emos dado e não pedido concurso. Seremos enfim aliados da Inglaterra." (CHAGAS, 1986, p. 132).

$O$ registo do encontro tenso de Aquilino com o embaixador, a 3 de Agosto, denuncia a clivagem profunda que os separa quanto à decisão de Portugal intervir ou manter-se neutral. Prefigura, em simultâneo, um choque nunca superado que, nesses anos, atravessou a sociedade portuguesa, a opinião pública, a instituição militar, os partidos e todo o poder político. A leitura cruzada dos diários destes dois protagonistas, que não posso levar agora a cabo, permite reconhecer a Grande Guerra como a ferida mais funda do regime republicano ${ }^{2}$. Transcrevo um pequeno excerto de diálogo em que Aquilino é posto em causa pelo seu oponente, tocando na tecla sensível da sua simpatia pela Alemanha:

- Deixou-se germanizar?

- Imagino que não. Pelo meus artigos na Capital, artigos que V. Ex ${ }^{\underline{a}}$ me deu a honra de aplaudir, sabe que sou contra o chauvinismo, todos os chauvinismos, contra a guerra, tôdas as guerras, mais nada! (RIBEIRO, 1934, p. 68)

A 24 de Agosto, sobe o tom do discurso quando anuncia, com lucidez premonitória, o atoleiro em que se enterrará o "[s]eu pobre e louco Portugal" (idem, p. 200) e adivinha-lhe mesmo um abismo idêntico ao de Alcácer-Quibir. Desafia então o país a entregar-se a uma reflexão séria, como se, em vez de um diário, proferisse uma conferência ou escrevesse um panfleto: no fundo, os portugueses ignoram que a guerra moderna exige "capacidade industrial e nervo económico da nação" (idem, p.201); ela sacrifica os seus homens ao móbil patriótico mas salvaguarda os mandantes e fazedores de opinião que, a despeito do seu belicismo, nunca irão para os campos de batalha.

Aquilino Ribeiro recusa pensar a entrada na guerra como uma prova de heroicidade; a sua posição é eminentemente moral e antibelicista. Daí o relevo retórico e altissonante das interrogações, como estas, que implicam um pathos contestário dos argumentos de João Chagas: "Em nome de que justa, necessária causa, se podem despachar para o matadoiro os meus pobres, ignorantes, pacíficos labregos?" (idem, p. 70) ou

Declarar guerra, atirar com milhares de pobres diabos para o maneta, exaurir o úbero chupado da nação, que é isso se há três - são três - magníficos Graais a conquistar: glorificar o nome português, sacudir a suzerania do leopardo, pagar o nosso tributo à civilização? (idem, p. 74) ${ }^{3}$

Não admira igualmente o tom lapidar com que descreve a lógica vã da guerra que, tarde ou cedo, varre para o canto da desmemória a barbárie repetidamente cometida pela humanidade:

Tudo isto é a canção do ódio. Amanhã por cima das fronteiras, ou com as fronteiras derrubadas, os povos dar-se-ão mãos fraternais. Se não amanhã, no dia em que os fomentadores da guerra, os candidatos a estátuas erguidas sôbre caveiras, e os fabricantes de canhão tenham baqueado. (idem, p. 256)

Também pelo hibridismo genológico de É a Guerra se torna imperativo reflectir acerca do processo editorial que lhe deu origem, sendo realizado em vida pelo próprio autor. Refiro-me ao trabalho invisível, para o leitor, que permitiu transformar a prática diarística num livro (cf. SANCHÉZ MORONI, 2006, p.112-120). Aliás, no volume subsequente a este, Alemanha Ensanguentada, também de 1934, incluem-se, num formato diarístico, quatro crónicas identificadas como "Notas de Viagem". São transcritas ipsis verbis, sob o título "Nos campos de Batalha", da revista Ilustração, onde Aquilino as havia publicado entre 1 de Janeiro e 1 de Março de $1929^{4}$.

Em É a Guerra também encontramos provas de uma arqueologia textual oriunda das crónicas. É fácil comparar várias entradas do diário com as "Cartas de Paris", textos jornalísticos que publicou entre 1910 e 1913, no periódico lisboeta $A$ Capital, aquando do primeiro exílio em Paris. Em 1913 esses textos focam a alarmante actualidade

\footnotetext{
2 Em 1929 é editado, por iniciativa da sua viúva, o Diário de João Chagas. Inclui os anos em que ocupou o posto de embaixador em Paris, em tempos de guerra e pós-guerra: vol. I (1914), vol. II (1915-1916), vol. III (1917) e vol. IV (1918-1921). Sobre esta matéria e de um ponto de vista historiográfico, cf. Novais, 2006.

3 Estes "pobres, ignorantes, pacíficos labregos" lembram o protagonista sobrevivente de "Chumbo", novela que Aquilino edita em Caminhos Errados (1947): o hortelão Zé Lambu, arrastado para as trincheiras da Flandres pelo amo, que o não quer para genro; depois para o campo de concentração alemão; para a fuga destemida sob o fogo de artilharia; até regressar à terra natal onde o seu sonho de amor se destrói dolorosamente.

4 Jorge Reis recolheu-as no volume II de uma antologia de textos jornalísticos póstumos de Aquilino Ribeiro, escritos no segundo exílio de Paris, com o título Páginas de Exílio 1927-1930 (cf. RIBEIRO, [1988b], p. 69-88).
} 
francesa, denunciam os perigos da eleição do presidente Raymond Poincaré, o chauvinismo antigermânico, o pretexto da questão da Alsácia e da Lorena ou a Lei dos três anos de serviço militar obrigatório. Em 12 de Fevereiro de 1913, fala, por exemplo, da "garra financeira da judiaria internacional e [da] garra institutrice da França" (RIBEIRO, [1988a], p.142). Não esquece também a "mentalidade de empréstimo" (ibidem) de Portugal que em tudo seguia subserviente o modelo francês, apesar de este incluir a boa inspiração dos valores republicanos.

Chamo a atenção para um caso de transplante e expansão de uma dessas crónicas: uma espécie de ficha de leitura de um livro publicado em 1913: Campagnes $d u$ Capitaine Marcel en Espagne et au Portugal 1808-18145. Trata-se das memórias de um militar francês nas Invasões Napoleónicas da Península Ibérica que dão azo a Aquilino para falar do fenómeno incivilizável que é a guerra e da impossibilidade de a refrear através de leis e convenções:

[...] não se civiliza; não é susceptível de progresso moral; não passa do jazigo de barbárie humana em erupção. Querer regulamentá-la, contrasenso; adoçá-la, ironia. A conferência da Haia, a Cruz Vermelha, o defeso das balas dum-dum, dos gases, do bombardeamento aéreo de cidades abertas é poeira, deliciosa poeira, que os politicantes, senhores do mundo, lançam aos olhos dos crédulos. (RIBEIRO, 1934, p. 138)

Luís Vidigal identifica nas crónicas aquilinianas uma "premência factual" (1988, p.174) que é patente em $E$ a Guerra. Nesse sentido, torna-se mais credível que Aquilino afirme, no prefácio do diário, que este é um registo "mal espanejado do pó dos anos e [que] àparte leves variantes, [ficou] como o lan[çou] ao papel" (RIBEIRO, 1934, p. 16), duas décadas antes, em 1914. Temos a documentação acima referida que o confirma. Há ainda a considerar a declaração de que, para a edição do livro, expurgou do diário "páginas em que [s]e arvorava em oráculo que lera o futuro com acerto, pois seria risível pospor a profecia aos próprios acontecimentos" (ibidem). Ficamos também a saber que não fez o mesmo com factos e comentários que o desmentiram a posteriori: no fim de contas, e as palavras são suas, "um cálculo errado de metereologia social não é menos instrutivo que um cálculo justo" (ibidem).

Em todo o caso, a composição e a dimensão do diário editado levam-no muito além da colecção de crónicas e anotações soltas, feitas ao sabor da febre de Paris que vai sendo cada vez mais retaguarda de uma guerra sangrenta.

\footnotetext{
5 A crónica original tem por título "Rememorando as Invasões Francesas. As violências, os latrocínios, os excessos praticados pelos franceses em Espanha e Portugal. Um testemunho insuspeito". Foi publicada em $A$ Capital, a 24 de Agosto de 1913, e está coligida no volume 1 de Páginas de Exílio (cf. RIBEIRO [1988a], p. 183-185).
}

O carácter fragmentário do género diário favorece por natureza a absorção de material de proveniência diversa, como aqui sucede. Ao referir o trabalho de revisão textual, evidencia-se também a humildade estratégica do escritor. Embora distanciado da génese primeira da obra, não o está da verdade de testemunho que reivindica para ela, ao caracterizá-la como "tôsco e vermelho granito dum caderno de guerra" (idem, p. 7).

O prefácio tenta justificar, com eficácia relativa, a censura sistemática que faz da França, dos seus políticos, dos seus jornais e do seu povo "acarneirado" (idem, p. 289) - a Alemanha, diz criticá-la "embora em menor escala" (idem, p. 8), por estar "confinado a um dos antípodas da guerra" (ibidem) e também pela "imoderada franqueza" (idem, p. 9) com que denuncia a mentira de que se fazem esta e todas as guerras. A 23 de Setembro declara o "pejo de viver, válido e moço, a meio duma população de velhos, mulheres e crianças, e de arrastar por esta pobre e grande terra, coberta de luto, lavada de sangue e de lágrimas, a insolência da [su]a neutralidade" (idem, p. 296). Recusa o qualificativo de germanófilo mas, neste livro, o ataque vai cerrado e constante na direcção da França. Denuncia sistematicamente a propaganda antigermânica e não esconde a duplicidade moral que as leis da guerra lhe impõem ao espírito, quando se indigna e ao mesmo tempo hesita em condoer-se com o destino da Bélgica invadida (idem, p. 94) ou com bombardeamentos alemães a Paris (idem, p. 235).

É a Guerra faz também o ajuste de contas com o fracasso da República em Portugal, seduzida pela aventura da guerra, que apelida de "nateiro de sangue" (idem, p. 157). Sem diminuir a lucidez e a informação de Aquilino, não posso deixar de notar que o tratamento dado à nossa entrada na I Guerra denuncia a interferência da revisão do texto para ser editado em livro. É verdade que, logo em Setembro de 1914, Portugal respondeu a ataques alemães em Angola e Moçambique mas não é esse palco de guerra a que este diário se refere; e ainda se estava longe do desastre do Corpo Expedicionário Português, na Flandres, em 1917 e 1918. Por isso, a voz do diarista parece incorporar os efeitos da revisão posterior que lhe permite tecer considerações tão contundentes e fundamentadas.

A violência do discurso é especialmente dirigida contra o mais radical dos intervencionistas, João Chagas, a cujo diário, publicado postumamente em 1929, Aquilino certamente respondia com o livro em estudo. Além disso, já regressado a Portugal e amnistiado pelo regime salazarista, em 1932, o escritor evoca, no prefácio do diário, a chama do Reviralho que resistiu à Ditadura Militar imposta em Maio de 1926. Daí que o abra com a dedicatória ao Dr. António Gomes Mota: seu companheiro no movimento insurreccional do regimento de Pinhel, 
em 1928, na detenção no presídio militar do Fontelo, em Viseu, e na fuga rocambolesca para Paris, onde viverá um segundo período de exílio até $1931^{6}$.

Por outro lado, a memória fixada no diário de 1914 dialoga intensamente com o contexto europeu que rodeia a sua edição: esse era já o tempo de uma Alemanha que se tornava "inimiga fidagal do género humano" (idem, p. 14), longe do aprumo que, no seu entender, a caracterizara historicamente. Com esses termos não abdica por completo da defesa da Alemanha: justifica a ascensão ao poder dos nazis pelo sacrifício a que o país fora condenado pelos vencedores da I Grande Guerra, no Tratado de Versalhes, e acaba por anunciar, em tom bíblico, a inevitabilidade de uma nova hecatombe mundial. ${ }^{7}$

Se as crónicas de 1913 e o diário É a Guerra não diferem muito no modo como escrutinam a actualidade francesa e europeia, com as devidas diferenças cronológicas, o livro traz a fluidez discursiva de um sujeito que deambula pelas ruas de Paris para tomar o pulso aos primeiros tempos de guerra. À primeira vista há muita rigidez argumentativa na palavra daquele que acusa, sem rodeios, os culpados da catástrofe em curso. Todavia, não esconde o incómodo que lhe causa o facto de viver uma mutação civilizacional sem precedentes naqueles primeiros anos de novecentos. Claro que está longe da análise de Lénine (2000) sobre a escalada imperialista do capitalismo que conduziu à guerra mundial: no essencial, sobre a disputa, à escala planetária, entre as grandes potências da época pelas matérias-primas e pelo domínio do capital financeiro, gerado a partir da fusão do capital bancário e industrial. ${ }^{8}$ Aquilino, por seu lado, faz uma leitura circular e moral do tempo histórico, embora não ignore o peso dos monopólios industriais na eclosão da guerra. Descreve-a pelo gigantesco poder de ruína e extermínio, pelo eterno "desembestar furioso" (RIBEIRO, 1934, p. 190) das forças mais bárbaras, activas "desde o troglodita, fabricante de pontas de silex, a Krupp, construtor dos canhões de aço" (ibidem).

\footnotetext{
6 Há, nesta passagem do prefácio, o travo de um tempo amargurado, quando refere indirectamente o presente de derrota dos republicanos como aquele seu companheiro e ele próprio: "As ilusões dêsse tempo [da insurreição reviralhista] voaram como as penas mortas do colo dos pombos correios, disparados céus fora; deixá-lo; criaram-se outras por mercê duma divindade eminentemente benigna, que dêste modo se compraz em defender os homens livres do pasmo e da amargura." (RIBEIRO, 1934, p. 7)

7 São estes os termos premonitórios de Aquilino Ribeiro: "Hitler desabrochou do nateiro de miséria, de opressão, de vexame, de rancor reprimido [...]. Aí teem Átila II. Por agora está a forjar o gládio; quando o tiver forjado, brandi-lo-á sobre a Europa espavorida e nada saberá resistir-lhe. É fatal. [...] Ainda não bateu a hora, mas já ergue a cerviz que os negociadores de Versalhes, nefastamente para o mundo, supuseram dobrada à escravidão para todo o sempre. Acabou-se; são chegados os tempos mais trágicos e fecundos na história do género humano; cinco anos para a Alemanha se armar; um até dois de hecatombe; dois de diabo à solta, e o dies irae. Para a treva, para a claridade?" (RIBEIRO, 1934, p. 15-16).

8 Refiro-me a O Imperialismo: Fase Superior do Capitalismo, escrito por V. I. Lenine em 1916 e publicado no ano seguinte.
}

Mas mais interessante do que aferir o apuro da análise histórico-social ou o grau de simpatia pela Alemanha será avaliar a percepção que o autor tem da cidade que se torna, em grande medida, mal-amada e motivo de observação perplexa e reactiva. Essa posição dúbia e desconfortável não obsta à precisão da análise e à agudeza do registo de reportagem. É precisamente nos apontamentos sobre a paisagem de Paris que o diário capta a essência do século XX a nascer com a guerra naquele Verão de 1914. A composição da paisagem humana funciona justamente como superfície de observação onde Aquilino mede a temperatura da vida parisiense e projecta não apenas opiniões e perplexidades mas também afectos e sensações de observador necessariamente implicado.

Já numa fase adiantada do livro, a 13 de Setembro, o problema parece não ser apenas o facto de se ver forte e saudável entre uma população doente e enlutada. Dia após dia foi tomando nota das cambiantes do lugar marcado por cada vez mais sinais da guerra. No entanto, se antes circulara entre a gente nas artérias, cafés e transportes públicos, nesse dia impõe-se-lhe uma alergia à multidão:

\begin{abstract}
Não saí à rua por isto tudo e ainda porque os movimentos das multidões, muito mais se os observamos duma janela com os olhos enquanto o cérebro vai seguindo em seus reflexos, são tão brutais e incompreensíveis como o fluxo e refluxo do mar. Não sou poeta, adoro o mar quando me banho nêle, mas deixa-me totalmente indiferente quando o contemplo do alto das arribas. Não penetro a razão, como devo dizer, cosmológica de massa de água tão extensa e insubmissa à vontade do homem. Pois a multidão é para mim como o mar, cega em seus impulsos, absurda nas finalidades. (idem, p. 272)
\end{abstract}

Esta aversão à multidão contrasta com o enlevo com que delineia matizes (atmosféricos e humanos) do ambiente urbano, captados repetidas vezes por um ângulo panorâmico, como no excerto seguinte:

Decidido a passar em casa a tarde remansosa do outono, encostei-me à janela. Como na manhã, a multidão não esbravejou; da cidade evolava-se apenas um pouco mais de sussurro, êste sussurro dominical das artérias de Paris que lembra colmeia colhendo o pólen dum jardim. (idem, p. 273)

Em Aquilino, impõe-se a aversão ao protagonismo político das massas que fizeram o ocaso da sociedade liberal burguesa da Belle Époque; "o fim do longo Verão" europeu, de 1815 a 1915, como lhe chamou George Steiner (1992, p. 15). As críticas implacáveis que lança à política $\mathrm{e}$ à imprensa francesas dão conta da sua reacção epidérmica à massificação da política nacionalista e à manipulação mediática a ela associada. Apesar das diferenças no grau de profundidade reflexiva sobre o assunto, não 
posso deixar de ligar esta exasperação aquiliniana com a imprensa do seu tempo à leitura que Walter Benjamin faz do fenómeno mediático. No capitalismo avançado, defende Benjamin em tom melancólico, a transmissão da experiência pela narrativa oral soçobra diante dos meios de comunicação massiva, vindo eles a ser fundamentais na expansão dos grandes movimentos de massas do seu tempo:

[...] com o domínio da burguesia que, na ascensão do capitalismo, vai ter a imprensa como um dos seus instrumentos mais importantes, surge uma forma de comunicação que [...] nunca influenciara anteriormente a forma épica de um modo determinante. Fá-lo agora. E verifica-se que essa forma de comunicação não é menos estranha à narrativa do que o romance, mas ameaça-a muito mais. Ela conduzirá aliás o próprio romance a uma crise. Esta nova forma comunicação é a informação. (BENJAMIN, 1992, p. 33)

Narrativa e informação são, deste modo, inconciliáveis. A primeira oferece reflexão, espanto e nunca se exaure; a segunda circula de forma efémera e apenas tem validade enquanto novidade.

Nesse sentifo, a democratização da vida política acarretou, a partir do último quartel do século XIX, a mobilização das massas para fins eleitorais, acompanhando a massificação dos meios de comunicação social, do mercado e dos universos do espectáculo e do divertimento (cf. HOBSBAWN, 1990, p. 132-140). Por tal motivo, Aquilino demarca-se desse indivíduo social, a multidão, cuja existência política é a "dos muitos enquanto muitos" (VIRNO, 2010, p. 402). Tem-na por monstruosa, acéfala e dissolvente pois compromete a racionalidade e o valor do indivíduo, na exacta medida em que é manipulada por símbolos e ritos de comunhão e lealdade à nação; a tal comunidade imaginária que, na modernidade, veio preencher o vazio de laços comunitários entretanto perdidos com a urbanização e a evolução do capitalismo. A expressão máxima dessa religião patriótica traduziu-se precisamente na massificação da guerra que, em nome da pátria, sacrificou os povos, sob o peso esmagador da tecnologia do armamento e da morte industrializada.

Mesmo se fixado na culpa do lado francês, $E$ E $a$ Guerra estuda com acerto o caldo de cultura ideológico do nacionalismo beligerante, difundido nas escolas e nas parangonas dos jornais e depois propagado nas conversas exaltadas de rua. O quotidiano parisiense começa a conhecer a pressão xenófoba, transposta em diálogos hostis entre franceses e estrangeiros. Assim acontece com Aquilino que é atacado por um passageiro no autocarro Montrouge-Motholon, um "boi de nora" (RIBEIRO, 1934, p. 29) nacionalista que lhe vocifera: " $A$ Paris, Monsieur, il y a trop de métèques!" (idem, p.28; itálico do texto).
À vivacidade do diálogo, reportado em discurso directo, segue-se a análise das origens da histeria patriótica e dos meios de manipulação ideológica que a ela conduziram:

Às pátrias é indispensável o culto dos heróis, o feito das armas, epopeia e lenda, exaltamento do eu colectivo como elemento de vinculação sentimental entre os indivíduos. Sem êste glacis em tôrno das consciências esboroar-se-iam as fronteiras. No intuito de evitar semelhante catástrofe, instituíram os interêsses criados a religião da pátria com seus curatos e prelazias. (idem, p. 30)

Entremeada na batalha argumentativa que é todo este diário, temos igualmente a escrita do repórter que parece manejar uma câmara na cidade. É assinalável como no meio de uma escrita programática e filosófica, se eleva, com certa regularidade, a finura do apontamento que regista o movimento, as formas, as cores, os sons do lugar. Convoca-se o motivo da visão de artista sobre a cidade moderna, modelada pela deambulação. Já a primeira entrada do diário, no sábado 1 de Agosto, mergulhara, em foco plongé, no quadro atmosférico de Paris, no remoinho da (então) Avenida de Orléans e numa vendedora de jornais, para regressar depois aos "rostos transidos [em que se] desenham em antecipação nervosa os frenesis e tremores da guerra" (idem, p. 18):

Na golfada de pessoas que, de instante a instante, o metropolitano atira para o céu aberto e se perdem na praça como grãos na geira, lastimam-se uns praguejam outros, mas sem o menor espalhafato. No entanto, apesar da exaltação, não se extinguiu a última esperança, cintila teimosa, à margem quási do rasoável, que sobretudo tremeluz no olhar das mulheres. Sim, ainda resta um ar de acomodamento. Clamava-o ontem na Humanité a voz de Jaurès, voz que o destino revestiu duma solenidade de além [...]. (ibidem)

Aquilino escolhe episódios parcelares, esboça personagens anónimas e as suas pequenas histórias de vida que dramatizam e humanizam a informação veiculada. Choca-se com um reclamo a roupa de luto estranhamente misturada com camélias (idem, p. 254) ou fixa, em croquis, o pormenor impressionista dos corpos femininos (das pernas, em concreto) a espalhar pelas ruas a nódoa negra do luto dos que choram na retaguarda da guerra: "Nas ruas, sim, onde até aqui a saia fendida segundo a moda deixava ver uma perna alvoroçante, rebrilham os crepes funerários. São os corvos doloridos da retaguarda que aparecem já por tôda a parte, isolados ou em bando." (idem, p. 255)

É, no entanto, quando capta a realidade a partir de casa que mais se embrenha e implica no que escreve; já vimos antes quão complexa é a relação que estabelece com a multidão aglomerada. Declara-o ostensivamente 
e leva-o à prática de cada vez que refere o seu espaço doméstico - o escritório ou simplesmente a janela -, tornando-se estes nos lugares privilegiados donde fixa e pensa a cidade lá fora. Assim sucede quase no remate da entrada de 16 de Agosto: "Ouço chorar ao lado da minha casa; ao côro de prantos sobrepõem-se os gemidos duma rapariguinha, tão altos que parecem uivos. Foi um homem, pai de filhos, que morreu na guerra." (idem, p. 160).

Dou um segundo exemplo onde a $3^{\underline{a}}$ pessoa verbal atenua mas não esconde a implicação pessoal, afectiva, de quem escreve e vive por dentro o espaço onde mora. $\mathrm{O}$ registo é dinâmico porque evolui do ponto de percepção da casa (sugerida pela sinédoque da volta da chave) até chegar à paisagem larga de Paris, com particular insistência nas sensações auditivas:

Dá-se volta à chave às dez horas e um cobertor de silêncio desce sôbre a cidade. Sente-se debaixo dêle não sei que anélito opresso; o anélito da ansiedade e da esperança primeiro, depois o arfar do pesadelo. Passam minutos... horas nesta morrinha até que um bêbedo, recebido à chucha-calada nos fundos duma tasca, solta em voz de estertor interjeições destas: poireau! (idem, p. 167)

A primeira frase do parágrafo ("Dá-se volta à chave às dez horas e um cobertor de silêncio desce sobre a cidade.") dá sinal da ligação entre a casa onde o escritor se recolhe e o exterior; o elo está na conjunção coordenada e na metáfora do cobertor que toma conta e coloniza o espaço da rua silenciosa. De seguida, fixa-se a "voz de estertor" (ibidem) de um bêbado e, finalmente, é como se pairasse, com um grande óculo, pela cidade toda, a começar pelo rio lúgubre: "O Sena corre barrento e surdo, mal harpejando os pilares das pontes; nestes dias não arrastou cadáver de costureiritas. Ninguém tem coragem de fechar os olhos em tão portentoso teatro." (ibidem).

Esta é porventura a passagem que mais aproxima a escrita aquiliniana do motivo moderno e modernista da cidade como paisagem vivida por dentro, como se de um ecrã mental se tratasse. As grandes massas das cidades tiveram presença forte no imaginário oitocentista, a ponto de se imporem como leitmotiv a muitos escritores desse século. O verso de Baudelaire, no soneto "A une passante", "La rue assourdissante autour de moi hurlait" (BAUDELAIRE, 1989, p. 118), pode funcionar como síntese desta questão. Walter Benjamin (1998, p.49-83) cita todo o texto baudelairiano, quando elege a figura do flâneur como o protagonista da modernidade: um sujeito melancólico que se entrega ao espectáculo massivo e mutante das ruas por onde deambula, excitado pelas galerias comerciais, exposições universais e panoramas.

Para falar da proximidade desfasada e dolorosa do sujeito pessoano com o espaço urbano, João Barrento fala até de uma "cidade translúcida" (1987, p. 86), encenada no Livro do Desassossego, na poesia ortónima ou de Álvaro de Campos. Ao ser avistada da janela, Lisboa ganha então os contornos do torpor estático do seu observador e funciona como um espaço-vertigem do interior em estilhaço (idem, p. 100-101). A estética modernista explora, em suma, a indistinção entre interior e exterior e a erosão do princípio de realidade e pertença. Daí a densidade do quadro urbano resultar do movimento deambulatório de um sujeito que olha e absorve a paisagem de fora, em função do seu interior, incoincidente consigo mesmo e com o mundo dos outros.

Que fique claro que não defendo que Aquilino explora em pleno a atenção dispersa e melancólica sobre as ruas e sobre si mesmo, a ponto de diluir fronteiras entre o enunciador e a paisagem. Ainda assim, o quadro nocturno da paisagem parisiense (acima transcrito) indicia, de modo discreto, uma forma de representação aberta às trocas com o mundo, sob o estímulo dos seres anódinos da cidade. Em momentos excepcionais de É a Guerra, o espaço urbano fica mesmo impregnado pela entidade perceptiva e pela sua temporalidade. Sendo a paisagem um efeito de sentido que depende da representação, é natural que a ela corresponda uma visão do mundo específica, com investimentos simbólicos próprios, construídos no texto. E na boa linhagem do romance romântico e da sua tendência para a percepção interiorizada do espaço (cf. BUESCU, 1990), a paisagem dispersa-se pelas sensações de quem a apreende de dentro e a escreve, cada vez mais, sob a forma do fragmento e da sinestesia. Essa passou a ser a prática da modernidade literária de novecentos que fundiu sujeito e espaço, tornando invisível o homem que olha a paisagem e que assim se dilui e impregna o cenário da representação (cf. idem, p. 98-108).

Para além de se colar à actualidade e de se distanciar da multidão, como forma de tomar uma posição antinacionalista em tempos de guerra, o diário É a Guerra faz reportagem de cidade e, mais ainda, serve para pensar a guerra. Daí que o autor cite algumas vezes a frase do título, quase ao modo de refrão, dando conta de uma evidência de todos os tempos que ganha novos contornos, diante dos seus olhos, em 1914. Por isso, não pode deixar de salientar os que, na primeira semana de Setembro, regressavam macerados do campo de batalha, incapazes de contarem a guerra:

Êsses combatentes, que se nos deparam pelas ruas coxeando ou amarfanhados num banco de jardim, pouco sabem dizer da guerra. Julguei de princípio que o troar da batalha e a brutal impressão os tivesse azoratado; engano; não sabem contar porque pouco ou nada viram. O seu horizonte era estreito como o campo abarcado por um binóculo em posição invariável. A guerra moderna despiu-se de tudo, até de paisagem. (RIBEIRO, 1934, p. 254-255) 
De forma lapidar Aquilino Ribeiro escolhe uma das razões possíveis para a falta de discurso dos soldados que primeiro experimentaram o inferno do campo de batalha, lugar de vazio, claustrofobia e absurdo. Walter Benjamin, em "O narrador", de 1936, virá a falar da mudez impotente dos soldados: entende-a como sintoma e sinal da devastação e desesperança, da vivência hostil e obcecante de toda uma época, ainda sob os efeitos da guerra de trincheiras e já sob o fantasma próximo do nazifascismo:

Uma geração que ainda fora à escola em ónibus puxado a cavalos viu-se indefesa, numa paisagem em que tudo se alterara excepto as nuvens. Sob elas, perdido num cenário dominado por forças destruidoras e explosões, o minúsculo e frágil corpo humano. (BENJAMIN, 1992, p. 28)

Se não se exime ao comentário acutilante da actualidade, Aquilino Ribeiro, com este seu caderno de guerra, redige um libelo antimilitarista e capta a essência inumana do século XX que então nasce. Um tempo colectivo que corrói os alicerces do mundo até aí conhecido, que vive a manipulação mediática e massacra, com irracionalidade e automatismo, milhões de corpos e almas. Quando, a 5 de Agosto, as companhias partem dos bastiões à roda de Paris com o destino da frente, os céus da cidade já absorvem a dor de quem fica e de quem se vai. O alarme do diarista exprime-se pelo apuro rítmico e geométrico da frase e pelo contraste cromático: "De hora a hora o céu escurece, amortalhado como catafalco; de hora em hora o sol ilumina a terra varrendo lutos e crepes. E neste jogo, brusquidão e claridade, se consome o dia." (RIBEIRO, 1934, p. 88).

Com o falhanço da batalha das fronteiras, travada entre a França e a Alemanha, debaixo do calor tórrido de Agosto, estabiliza-se a frente ocidental e a prioridade passa a ser cavar trincheiras (cf. MARTELO, 2010, p. 112). Daí em diante, estando materialmente ausentes do campo de visão do eu que escreve o diário, porque focado em Paris, as trincheiras passam a ser o lugar que não (se) vê mas que pesa em crescendo na sua paisagem atmosférica e humana. São uma espécie de contracampo inumano da cidade que a vai aos poucos ensombrando e submetendo, sob peso da "inevitável floração da guerra" (RIBEIRO, 1934, p. 284).

\section{Referências}

BAUDELAIRE, Charles. Les fleurs du mal suivies de Petits poèmes en prose, Curiosités esthétiques, L'art romantique, Journaux intimes (extraits), La Fanfarlo. Préf. et commentaires Robert Sctric. Paris: Presses Pocket, 1989.
BENJAMIN, Walter. O narrador. Reflexões sobre a obra de Nikolai Lesskov. In: Sobre arte, técnica, linguagem e política. Intr. T. W. Adorno. Lisboa: Relógio d'Água, 1992. p. 27-57.

BENJAMIN, Walter. El Paris del Segundo Império en Baudelaire. In: Iluminaciones II. Poesia y capitalismo. Prólogo y trad. Jesús Aguirre, Madrid: Taurus, 1998. p. 21-120.

BARRENTO, João. Figuras da modernidade na poesia urbana: de Baudelaire a Pessoa. In: $O$ espinho de Sócrates: Expressionismo e modernismo. Lisboa: Presença, 1987. p. 85-101.

BUESCU, Helena Carvalhão. Incidências do olhar: Percepção e representação. Natureza e registo descritivo na evolução do romance romântico (Portugal, França, Inglaterra). Lisboa: Caminho, 1990.

CHAGAS, João. Diário I. 1914. Prefácio João B. Serra. Lisboa: Rolim, 1986.

HOBSBAWN, Eric. A era do Império (1875-1914). Lisboa: Presença, 1990

LEJEUNE, Philippe. "Continue et discontinu". In: Signes de vie: Le pacte autobiographique 2. Paris: Seuil, 2005. p. 73-90.

LÉNINE, V.I. O imperialismo: Fase superior do capitalismo. Lisboa: Avante!, 2000.

MARTELO, David. Estabilização da Frente Ocidental. In: AFONSO, Aniceto Afonso; GOMES, Carlos Matos (Dir.). Portugal e a Grande Guerra 1914-1918. Matosinhos: Quidnovi, 2010. p. 112-117.

NOVAIS, Noémia Malva. João Chagas: A diplomacia e a guerra (1914-1918), Coimbra: Minerva, 2006.

RIBEIRO, Aquilino. É a guerra: Diário. Lisboa: Bertrand, 1934

RIBEIRO, Aquilino. Páginas do exílio: Cartas e crónicas de Paris. 1908-1914. Recolha de textos e org. Jorge Reis. Lisboa: Vega, [1988a]. Vol. 1.

RIBEIRO, Aquilino. Páginas do exílio: Cartas e crónicas de Paris. 1927-1930. Recolha de textos e org. Jorge Reis. Lisboa: Vega, [1988b]. Vol. 2.

SANCHÉZ MORONI, Andréia. La edición de la intimidad: Diarios íntimos y sus procesos editoriales. Trabalho apresentado como requisito para a obtenção do título de Master no âmbito do Programa de Doutoramento em Teoria da Literatura e Literatura Comparada do Departamento de Filologia Espanhola/ Universidad Autónoma de Barcelona, 2006. 130fls.

STEINER, George. No castelo do Barba Azul: algumas notas para a redefinição da cultura. Lisboa: Relógio d'Água, 1992.

VIDIGAL, Luís. Recensão de Jorge Reis, Aquilino em Paris e Páginas de exílio. Colóquio/Letras, n. 104-105, p. 173-175, jul. 1988.

VIRNO, Paolo. Multidão e princípio de individuação. In: DIAS, Bruno Peixe; NEVES, José (Dir.). A política dos muitos: povo, classes e multidão. Lisboa: Tinta-da-China, 2010. p. $393-405$.

Recebido: 23 de outubro de 2013 Aprovado: 14 de fevereiro de 2014 Contato: ccarmo@ualg.pt 